\title{
An Overview of Major Finfish Species Landing in Chellanam Harbour of Ernakulam District, Kerala (India) and their Conservation Status
}

\author{
Davood Nihal $^{1 *}$, N.M. Naseem ${ }^{2}$, N.S. Surjith ${ }^{1}$ and C. Mohammed Salih ${ }^{1}$ \\ ${ }^{1}$ Department of Aquatic Environment Management, ${ }^{2}$ Department of Fisheries Resource \\ Management, KUFOS, Kochi, India \\ *Corresponding author
}

\begin{tabular}{l} 
Ke y w o r d s \\
$\begin{array}{l}\text { Fish diversity, } \\
\text { Chellanam, IUCN } \\
\text { red list, } \\
\text { Conservation status }\end{array}$ \\
Article Info \\
\hline $\begin{array}{l}\text { Accepted: } \\
\text { 26 July } 2020 \\
\text { Available Online: } \\
\text { 10 August } 2020\end{array}$ \\
\hline
\end{tabular}

A B S T R A C T

The present study primarily focused on systematic representation of IUCN (International Union for Conservation of Nature) Red Listed marine finfish landings of Chellanam harbour of Ernakulam district, Kerala. The study was conducted for a period of 6 months from November 2018 to April 2019. Sample collections were conducted twice in a month. A checklist of finfishes along with their scientific name, common name, family and present conservation status were prepared. A total of 41 species of fishes belonging to 24 families were identified during the entire study. As per IUCN (International Union for Conservation of Nature) Red List (2017-3), out of 41 fish species identified, 1 species comes under Near Threatened (NT), 1 species comes under Vulnerable (VU), 2 species comes under Data Deficient (DD), 31 species comes under Least Concern (LC) and 6 species comes under Not Evaluated (NE). Information on conservation status of fishes plays a significant role in fisheries science since it forms basis for management of marine fishery resources.

\section{Introduction}

As a tropical country, India boasts a rich diversity of flora and fauna and is listed among the world's mega biodiversity countries, however with a delicate ecosystem (Yadav, 1997). As fishery resources have multiple uses, fishing has become a major industry in developing countries such as India and has provided livelihoods for a number of people. Fishery resources are sustainable natural resources, yet are liable to extinction (as witnessed in several cases worldwide) if persistent and indiscriminate harvesting is adopted (Narayanakumar, 2017). Marine ecosystems are ecologically significant as they support high biodiversity and a wide range of fish species, but these coastal environments are remarkably sensitive to increasing anthropogenic activities and 
related climate changes (Luypaert et al., 2019). There is growing concern about the increasing human effect that has occurred in recent years on marine biodiversity (Jackson, 2010). According to (Joshy, 2017) marine and coastal waters of Kerala are considered as the most significant ecosystems in terms of productivity and uniqueness. Highly flourished marine resources, abundant number of fish diversity and skilled fishing community are the driving forces which lead Kerala into a major producer and consumer in the field of fisheries. Favourable high rainfall, long coastline and a numerous numbers of rivers make the Kerala coast more productive for fishery. The Chellanam fishing harbour is a small fishing harbour, situated in the Kandekkadu gap of Chellanam Panchayath in Ernakulam District of Kerala. This region is rich in fishery resources and often mudbanks are formed here. The nearest established fishing port is at Thoppumpady, $20 \mathrm{~km}$ north of Chellanam, where there is no beach landing facility. The fishermen engaged in fishing and related activities here are from South Chellanam Matsyagramam. About 220 motorized boats called valloms and 25 inboard valloms are operating from this area. The assessment of the major marine fish reported from the study area with categories and criteria of IUCN (International Union for Conservation of Nature) Red List not only determines their conservation status but also helps to formulate sustainable fisheries management strategies. The present work is an effective attempt to identify major finfishes and determine the conservation status, reported in the Chellanam harbour of Ernakulam district.

\section{Materials and Methods}

The study area (Lat. $09^{\circ} 47^{\prime} 950^{\prime \prime} \mathrm{N}$, Long. $\left.76^{\circ} 16^{\prime} 551^{\prime \prime} \mathrm{E}\right)$ is located in the Chellanam Panchayath of Ernakulam District (Fig. 1), 250 metres west of Thoppumpady -
Chellanam State Highway and $8.5 \mathrm{~km}$ from the N.H 47 at Eramalloor junction. Investigation regarding fish landing along with sample collection were conducted twice in a month and harbour visit were made on early morning (6 A.M) for a period of six months from November 2018 to April 2019. All images of fishes were captured with a Canon IXUS 190 digital camera. The collected fishes were identified using standard references and keys (Misra, 1952; Ebert and Mostarda, 2013; List of Fish Species; Fish Base). During the auction time, the fish samples were collected randomly from each heap. All collected samples were brought to the laboratory, washed thoroughly with tap water, and stored in $10 \%$ formalin for further examination. To supplement the sampling data, information regarding other than reported catch was collected from fishermen by questionnaire survey method. The fishes identified were classified in compliance with the status of the IUCN (International Union for Conservation of Nature) Red List and also the different schedules of the Indian Wildlife Act (Protection) and the appendices of the Convention on International Trade in Endangered Species of Wild Fauna and Flora (CITES) (IUCN Red List 2017-3).

\section{Results and Discussion}

A total of 41 species of fishes belonging to 24 families were identified during the entire study. Scientific names of the 41 species of fishes, with family, common name and IUCN status are shown in Table 1 and the details of number of species representing each family are shown in figure 3. Out of 24 families, Engraulidae dominated first with five species of fishes including Encrasicholina punctifer, Stolephorus commersonnii, Stolephorus indicus, Thryssa mystax and Thryssa setirostris. Carangidae and Clupeidae secondly dominated representing 4 species from each family. Families of Tetradontidae, 
Hemiramphidae, Leiognathidae, Scombridae, Syonodontidae, Belonidae and Terapontidae represented 2 species from each family. Families of Ambassidae, Ariidae, Chanidae, Dussumieriidae, Serranidae, Cichlidae,
Fistularidae, Gerreidae, Lactaridae, Menidae, Mugilidae, Pristigasteridae, Sciaenidae, and Sillaginidae represented 1 species from each family.

Table.1 Different fish species with conservation status recorded during the study

\begin{tabular}{|c|c|c|c|c|}
\hline Sl. No & Species Name & Common Name & Family & $\begin{array}{l}\text { IUCN } \\
\text { Status }\end{array}$ \\
\hline 1. & Ablennes hians (Valenciennes, 1846) & Flat needle fish & Belonidae & LC \\
\hline 2. & Alepes djedaba (Forsskal,1775) & Shrimp scad & Carangidae & LC \\
\hline 3. & Ambassis dussumieri (Cuvier, 1828) & Malabar glassy perchlet & Ambassidae & LC \\
\hline 4. & Amblygaster sirm (Walbaum,1792) & Spotted sardinella & Clupeidae & LC \\
\hline 5. & Arius arius (Thunberg, 1792) & Threadfin sea catfish & Ariidae & LC \\
\hline 6. & Arothron leopardus (Day, 1878) & Banded leopardblowfish & Tetradontidae & DD \\
\hline 7. & Atule mate (Cuvier, 1833) & Yellowtail scad & Carangidae & LC \\
\hline 8. & Chanos chanos (Forsskal 1775) & Milkfish & Chanidae & LC \\
\hline 9. & Dussumieria acuta (Valenciennes, 1847) & Rainbow sardine & Dussumieriidae & LC \\
\hline 10. & Encrasicholina punctifer (Fowler, 1938) & Buccaneer anchovy & Engraulidae & LC \\
\hline 11. & Epinephelus diacanthus (Valenciennes, 1828) & Spinycheek Grouper & Serranidae & LC \\
\hline 12. & Escualosa thoracata (Valenciennes, 1847) & White sardine & Clupeidae & LC \\
\hline 13. & Etroplus suratensis (Bloch, 1790) & Pearlspot & Cichlidae & LC \\
\hline 14. & Fistularia petimba (Lacepede, 1803) & Red cornetfish & Fistularidae & LC \\
\hline 15. & Gerres filamentosus (Cuvier, 1829) & Whipfin silver-biddy & Gerreidae & LC \\
\hline 16. & Hemiramphus far (Forsskal,1775) & Black-barred halfbeak & Hemiramphidae & NE \\
\hline 17. & Hemiramphus marginatus (Forsskal,1775) & Yellowtip halfbeak & Hemiramphidae & $\mathrm{NE}$ \\
\hline 18. & $\begin{array}{l}\text { Lactarius lactarius (Bloch and } \\
\text { Schneider, 1801) }\end{array}$ & False trevally & Lactariidae & $\mathrm{NE}$ \\
\hline 19. & $\begin{array}{l}\text { Lagocephalus inermis (Temminck and } \\
\text { Schlegel,1850) }\end{array}$ & Smooth blaasop & Tetradontidae & LC \\
\hline 20. & Leiognathus equlus (Forskkal,1775) & Common ponyfish & Leiognathidae & LC \\
\hline 21. & Megalaspis cordyla (Linnaeus, 1758) & Torpedo scad & Carangidae & LC \\
\hline 22. & Mene maculate (Bloch and Schneider,1801) & Moonfish & Menidae & $\mathrm{NE}$ \\
\hline 23. & Mugil cephalus (Linnaeus, 1758) & Flathead grey mullet & Mugilidae & LC \\
\hline 24. & Opisthopterus tardoore (Cuvier, 1829) & Tardoore & Pristigasteridae & LC \\
\hline 25. & Otolithes ruber (Bloch and Schneider, 1801) & Tigertooth croaker & Sciaenidae & $\mathrm{NE}$ \\
\hline 26. & Photopectoralis bindus (Valenciennes, 1835) & Orangefin ponyfish & Leiognathidae & $\mathrm{NE}$ \\
\hline 27. & Rastrelliger kanagurta (Cuvier, 1816) & Indian mackerel & Scombridae & DD \\
\hline 28. & Sardinella longiceps (Valenciennes, 1847) & Indian oil sardine & Clupeidae & LC \\
\hline 29. & Saurida tumbil (Bloch,1795) & Greater lizardfish & Synodontidae & LC \\
\hline 30. & Saurida undosquamis (Richardson,1848) & Brushtooth lizardfish & Synodontidae & LC \\
\hline 31. & Scomberoides tol (Cuvier, 1832) & Needlescaled queenfish & Carangidae & LC \\
\hline 32. & Scomberomorus commerson (Lacepede, 1800) & $\begin{array}{l}\text { Narrow-barred Spanish } \\
\text { Mackerel }\end{array}$ & Scombridae & NT \\
\hline 33. & Sillago sihama (Forsskal,1775) & Silver sillago & Sillaginidae & LC \\
\hline 34. & Stolephorus commersonnii (Lacepede, 1803) & Commerson's anchovy & Engraulidae & LC \\
\hline 35. & Stolephorus indicus (van Hasselt,1823) & Indian anchovy & Engraulidae & LC \\
\hline 36. & Tenualosa toli (Valenciennes, 1847) & Toli shad & Clupeidae & VU \\
\hline 37. & Terapon jarbua (Forsskal,1775) & Jarbua terapon & Terapontidae & LC \\
\hline 38. & Terapon theraps (Cuvier, 1829) & Largescaled terapon & Terapontidae & LC \\
\hline 39. & Thryssa mystax (Bloch and Schneider,1801) & Moustached thryssa & Engraulidae & LC \\
\hline 40. & Thryssa setirostris (Broussonet, 1782) & Longjaw thryssa & Engraulidae & LC \\
\hline 41. & Tylosurus crocodiles (Peron and Lesuer,1821) & Hound needle fish & Belonidae & LC \\
\hline
\end{tabular}


Fig.1 Map showing study area $(\bullet)$

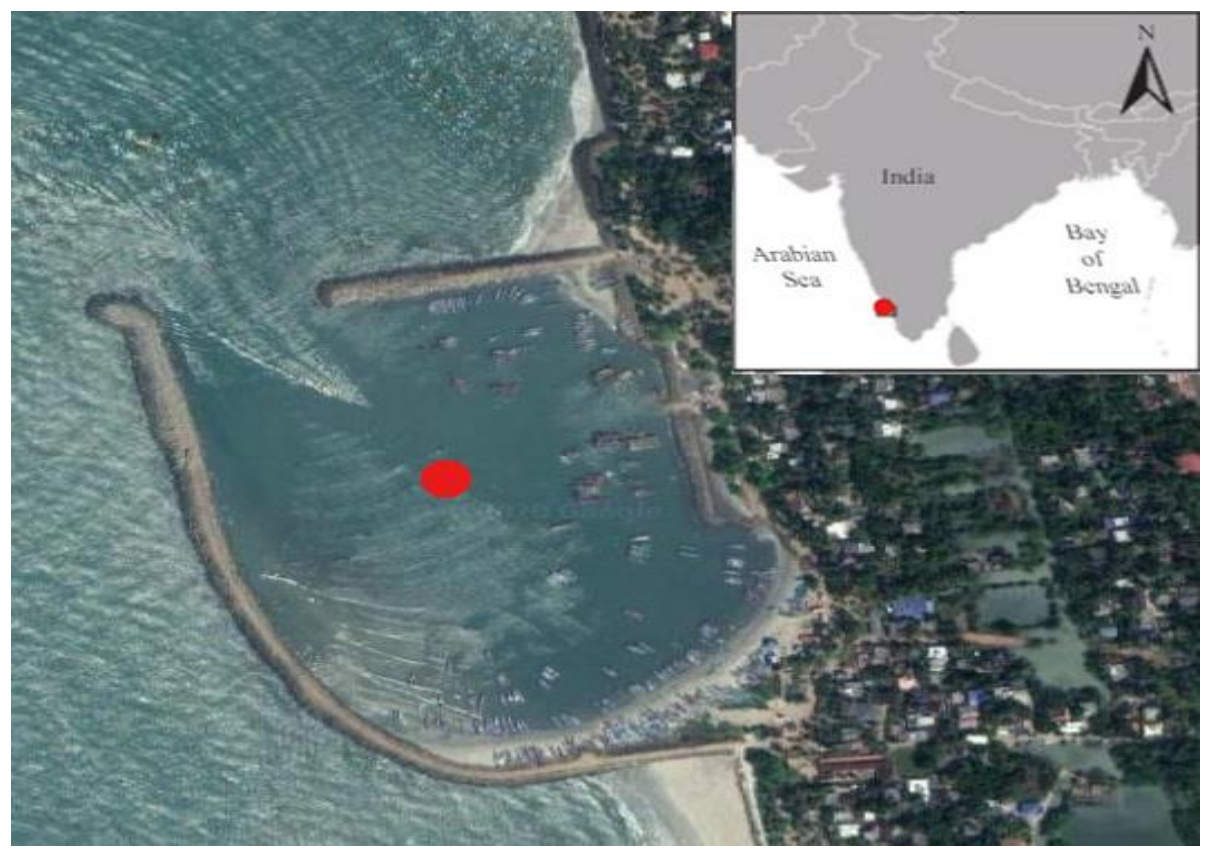

Fig.2 Graph showing No: of fish species reported with respect to various families

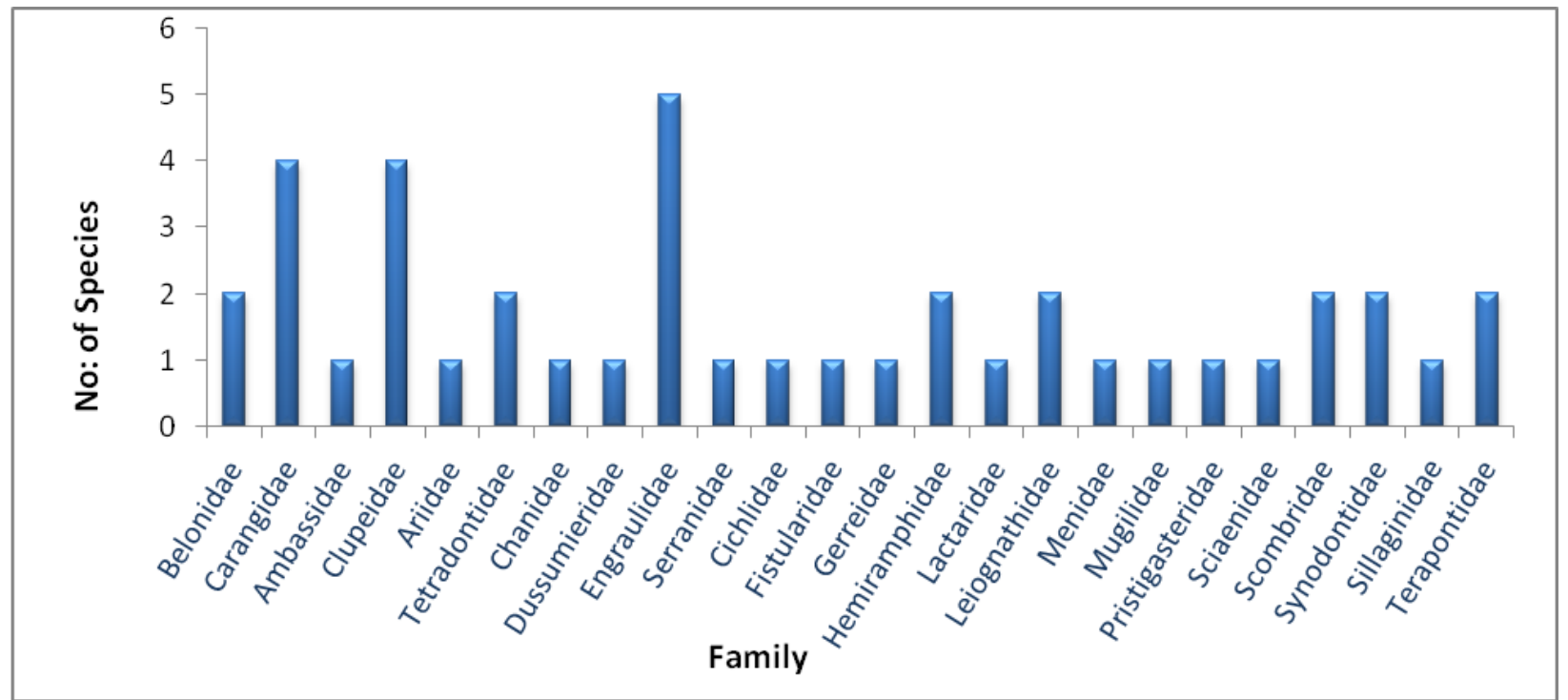

Based on the rate of decline, population size, geographic distribution area, degree of population and distribution fragmentation, IUCN (International Union for Conservation for Nature) Red List (2017-3) categorized the species into nine groups including Extinct (EX), Extinct in the wild (EW), Critically Endangered (CR), Endangered (EN),
Vulnerable (VU), Near Threatened (NT), Least Concern (LC), Data Deficient (DD) and Not Evaluated (NE). As per the knowledge from IUCN Red List, out of 41 fish species identified, 1 species comes under Near Threatened (NT), 1 species comes under Vulnerable (VU), 2 species comes under Data Deficient (DD), 31 species comes under Least 
Concern (LC) and 6 species comes under Not Evaluated (NE) so far.

The Chellanam fishing harbour is a small fishing harbour with a very clean and tidy environment. The people engaged in fishing in this area are from the Chellanam area itself. The harbour is required to have more infrastructural facilities as a large number of people are dependent on this place for their livelihood activities. Study results reveals that the Chellanam harbour is blessed with landing of wide variety of fish species. The conservation and management of endangered fish species is important for the sustainability of the coastal ecosystems. According to Shukla and Singh (2013) the best strategy towards the conservation of a species is to disseminate information, knowledge and awareness about the danger and extinction of species as preservation is not only desirable but also is cheaper than thinking of ways for recalling the extinct species. Fish fauna of the coastal waters of Kerala (Vincent et al., 2018) are being threatened due to several anthropogenic activities, habitat destruction and pollution. All of these activities would slowly diminish the biodiversity in the region. Thus awareness programmes amongst the fishers, strict ban on illegal monsoon fishing, usage of proper mesh sized nets and protection of breeding ground should be encouraged.

Studies of (Grafton et al., 2006) stated that "In an open access regime such as fisheries, there are many negative externalities which mean that unregulated fisheries are bound to end up in what is called the commons tragedy". This work will provide ideal data on major finfish landings in Ernakulam district's Chellanam harbour, India's southwest coast, and it may be inevitable in further fisheries based management and conservation strategies.

\section{Acknowledgements}

Authors are grateful to Kerala University of Fisheries and Ocean Studies, Panangad, Kochi

\section{References}

CMFRI, FRAD. 2019, "Marine Fish Landings in India-2018".

CMFRI, FRAD. 2020,"Marine Fish Landings in India-2019".

Ebert D.A., and Mostarda E., 2013, Identification guide to the deep-sea cartilaginous fishes of the Indian Ocean, Fish Finder Programme, FAO, Rome, pp. 76.

Froese, R. and D. Pauly. 2019. Fish Base.

Grafton, R. Q., James Kirekly, Toom Kompas and Dale Squires, 2006. Economics of Fisheries Management. Ashgate Publishing Company, England, p.160.

IUCN Standards and Petitions Subcommittee, 2017, Guidelines for Using the IUCN Red List Categories and Criteria. Version 13, Prepared by the Standards and Petitions Subcommitte.

IUCN, 2017. The IUCN Red List of Threatened Species. Version 2017-3.

Jackson J.B.C., 2010, The future of the oceans past, Philosophical Transactions of the Royal Society B: Biological Sciences, 365: 3765-3778.

Jhingran, V. G. 1991. Fish and Fisheries of India, Hindustan Publishing Corp. India) New Delhi 727p

Joshi, K. K. 2012. Marine Biodiversity of Kerala. Kerala Calling, 32(9), 34-37.

Joshi, K. K. 2017. Marine Ichthyofaunal diversity of India.

Luypaert, T., Hagan, J. G., McCarthy, M. L., and Poti, M. 2020. Status of marine biodiversity in the Anthropocene. In YOUMARES 9-The Oceans: Our Research, Our Future (pp. 57-82). Springer, Cham. 
Misra K.S., 1952, An aid to the identification of fishes of India, Burma and Ceylon, I. Elasmobranchii and Holocephali, Records of the Indian Museum, 49(1): 89-137.

Nair, R. J., Manojkumar, P. P., Zacharia, P. U., Mohamed, K. S., Sathianandan, T. V., Kuriakose, S., and Pillai, S. L. 2015. Status of marine fisheries of Kerala. Marine Fisheries Information Service; Technical and Extension Series, (226), 22-26.

Nair, V. R. 2009. Mapping of fisheries resources at panchayat level using GIS.

Naomi, T. S., George, R. M., Sreeram, M. P., Sanil, N., Balachandran, K., Thomas, V. J., and Geetha, P. M. 2011. Finfish diversity in the trawl fisheries of southern Kerala. Marine Fisheries Information Service, (207), 11-21.

Narayanakumar, R. 2017. Maximum economic yield and its importance in fisheries management.
Shukla, P., and Singh, A. 2013. Distribution and diversity of freshwater fishes in Aami River, Gorakhpur, India. Advances in Biological Research, 7(2), 26-31.

Vijayan, V., Edwin, L., and Ravindran, K. 2000. Conservation and management of marine fishery resources of Kerala State, India. Naga, the ICLARM Quarterly, 23(3), 6-9.

Vincent, P. D., Krismankutty, S., Joseph, A. C., and Mohamed Hatha, A. A. 2018. Landings of IUCN Red List finfishes at three major fishing harbours of South West coast of India. International Journal of Aquaculture, 8(8), 53-64.

Yadav B.E., 1997, Studies on systematics and zoogeography of the fishes of Western Ghats with observations on the status of endemic species, Ph.D. Thesis submitted to Shivaji University, India.

\section{How to cite this article:}

Davood Nihal, N.M. Naseem, N.S. Surjith and Mohammed Salih, C. 2020. An Overview of Major Finfish Species Landing in Chellanam Harbour of Ernakulam District, Kerala (India) and their Conservation Status. Int.J.Curr.Microbiol.App.Sci. 9(08): 3324-3329. doi: https://doi.org/10.20546/ijcmas.2020.908.382 